4. Boileau P, Krishnan SG, Tinsi L et al. (2002) Tuberosity malposition and migration: reasons for poor outcomes after hemiarthroplasty for displaced fractures of the proximal humerus. J Shoulder Elbow Surg 11: 401-412

5. Boileau P, Coste JS, Ahrens PM, Staccini P (2002) Prosthetic shoulder replacement for fracture: results of the multicenter study. In: Walch G, Boileau P, Mole D (eds) 2000 shoulder protheses: two to ten year follow up. Sauramps Medical, Montpellier, pp 561-573

6. Bondi R, Ceccarelli E, Campi S, Padua R (2005) Shoulder arthoplasty for complex humeral fractures. J Orthopaed Traumatol 6: 57-60

7. Boss AP, Hintermann B (1999) Primary endoprosthesis in comminuted humeral head fractures in patients over 60 years of age. Int Orthop 23: 172174

8. Brunner U, Boileau P, Köhler S (2006) Ergebnisse und Konsequenzen in der Prothetik au einer großen Multicenterstudie. In: Lill H (Hrsg) Die proximale Humerusfraktur. Thieme, Stuttgart New York, S 163-173

9. Frankle MA, Mighell A (2001) Outcomes of hemiarthroplasty for fractures of the proximal humerus. 8th ICSS, Cape Town, South Africa

10. Frankle MA, Ondrovic LE, Markee BA et al. (2002) Stability of tuberosity reattachment in proximal humeral hemiarthroplasty. J Shoulder Elbow Surg 11: 413-420

11. Frich LH, Sojbjerg JO, Sneppen O (1991) Shoulder arthroplasty in complex acute and chronic proximal humeral fractures. Orthopedics 14: 949-954

12. Gerber C, Schneeberger AG, Vinh TS (1990) The arterial vascularization of the humeral head. An anatomical study. J Bone Joint Surg Am 72: 14861494

13. Gierer P, Simon C, Gradl G et al. (2006) Die Humeruskopfmehrfragmentfraktur-Versorgung mit einer Prothese? Orthopade 35: 834-840

14. Habermeyer P, Magosch P (2006) Frakturprothetik. In: Lill H (Hrsg) Die proximale Humerusfraktur. Thieme, Stuttgart New York, S 135-162

15. Heers G, Torchia ME (2001) Shoulder hemi-arthroplasty in proximal humeral fractures. Orthopade 30: 386-394

16. Hempfing A, Leunig M, Ballmer FT, Hertel R (2001) Surgical landmarks to determine humeral head retrotorsion for hemiarthroplasty in fractures. J Shoulder Elbow Surg 10: 460-463

17. Hertel R, Hempfing A, Stiehler M, Leunig M (2004) Predictors of humeral head ischemia after intracapsular fracture of the proximal humerus. J Shoulder Elbow Surg 13: 427-433

18. Hertel R (2005) Fractures of proximal humerus in osteoporotic bone. Osteoporos Int 16: 65-72

19. Hessmann MH, Rommens PM (2001) Osteosynthesetechniken bei der proximalen Humerusfraktur. Chirurg 72: 1235-1245

20. Kralinger $F$, Schwaiger $R$, Wambacher $M$ et al. (2004) Outcome after primary hemiarthroplasty for fracture of the head of the humerus. J Bone Joint Surg Br 86: 217-219

21. Kwon YW, Zuckerman JD (2005) Outcome after treatment of proximal humeral fractures with humeral head replacement. Instr Course Lect 54: 363-369

22. Langdon AH, Estes WJ, Murray CA, Friedman RJ (1998) Shoulder arthroplasty for proximal humeral fractures. Orthop Clin North Am 29: 467-475
23. Levy J, Frankle M, Mighell M, Pupella D (2007) The use of the reverse shoulder prosthesis for the treatment of failed hemiarthroplasty for proximal humeral fracture. J Bone Joint Surg Am 89: 292300

24. Lill H, Voigt C (2006) Humeral shoulder fractueprosthesis. OP-Video, Arthrex, Karlsfeld, Germany

25. Loebenberg MI, Jones DA, Zuckerman JD (2005) The effect of greater tuberosity placement on active range of motion after hemiarthroplasty for acute fractures of the proximal humerus. Bull Hosp Joint Dis 62: 90-93

26. Marquass B, Hepp P, Voigt C (2006) Grundlagen. In: Lill H (Hrsg) Die proximale Humerusfraktur. Thieme, Stuttgart New York, S 1-14

27. Meyer C, Alt V, Hassanin H et al. (2005) The arteries of the humeral head and their relevance in fracture treatment. Surg Radiol Anat 27: 232-237

28. Mighell MA, Kolm GP, Collinge CA, Frankle MA (2003) Outcomes of hemiarthroplasty for fractures of the proximal humerus. J Shoulder Elbow Surg 12: 569-577

29. Misra A, Kapur R, Maffulli N (2001) Complex proximal humeral fractures in adults - a systematic reviwe of management. Injury 32: 363-372

30. Moskal MJ, Campbell B, Smith KL, Matsen FA III (1999) A radiographic analysis of 122 failed shoulder arthroplasties. Presented at: American Academy of Orthopaedic Surgeons 66th Annula Proceedings, Anaheim/CA, USA

31. Murachovsky J, Ikemoto RY, Nascimento LG et al. (2006) Pectoralis major tendon reference (PMT): a new method for accurate restoration of humeral length with hemiarthroplasty for fracture. J Shoulder Elbow Surg 15: 675-678

32. Norris TR, Green A, McGuigan FX (1995) Late prosthetic shoulder arthroplasty for displaced proximal humerus fractures. J Shoulder Elbow Surg 4: $271-$ 280

33. Phipatanakul WP, Norris TR (2005) Indications for prosthetic replacement in proximal humeral fractures. Instr Course Lect 54: 357-362

34. Plausinis D, Kwon YW, Zuckerman JD (2005) Complications of humeral head replacement for proximal humeral fractures. Instr Course Lect 54: 371380

35. Prakash U, McGurty DW, Dent JA (2002) Hemiarthroplasty for severe fractures of the proximal humerus. J Shoulder Elbow Surg 11: 428-430

36. Rockwood CA, Matsen FA (1998) The shoulder, 2nd edn. Saunders, Philadelphia

37. Voigt C, Lill H (2006) Indikation zur Operation und operative Differenzialtherapie. In: Lill H (Hrsg) Die proximale Humerusfraktur. Thieme, Stuttgart New York, S 135-162

38. Walch G, Boileau P, Mole D (eds) (2001) 2000 Prosthesis d'Epaule recul de 2 a 10 ans. Sauramps Medical, Montpellier
Orthopäde $2007 \cdot 36: 1012$

DOl 10.1007/s00132-007-1173-5

Online publiziert: 1. November 2007

(c) Springer Medizin Verlag 2007

R. Putz · H. Mühlhofer $\cdot$ Y. Ercan

Anatomische Anstalt, Ludwig-

Maximilians-Universität, München

\section{Bänder des Kniegelenks}

\section{Der Orthopäde (2007) 36:612-619}

Der Autor macht darauf aufmerksam, dass die Legende zu Abb. 5, S. 617, fehlerhaft ist.

Die Legende lautet korrekt:

Abb. 5 Anheftungsflächen der Kreuzbänder am Femur (rechts): a Ursprung des Lig. cruciatum anterius, Ansicht der Innenfläche des lateralen Kondylus. b Ursprung des Lig. cruciatum posterius, Ansicht der Innenfläche eines medialen Kondylus

Die Bezeichnungen „lateralen“ und „medialen" sind in der Druckfassung leider vertauscht.

\section{Korrespondenzadresse}

Prof. Dr. R. Putz

Anatomische Anstalt, Ludwig-Maximilians-Universität, Pettenkoferstraße 11, 80336 München reinhard.putz@med.uni-muenchen.de
Die Online-Version des Originalartikels können Sie unter http://dx.doi.org/10.1007/s00132-0071108-1 finden. 